\title{
腹腔鏡下に摘出した尿膜管蓑胞に類似するmesothelial cystの一例
}

田附興風会医学研究所北野病院産婦人科 ${ }^{11}$ 、同病理部 ${ }^{2)}$

榊原敦子 ${ }^{1)}$ 、永野忠義 ${ }^{1)}$ 、宇治田麻里 ${ }^{1)}$ 、佛原悠介 ${ }^{1)}$ 、宮田明未 ${ }^{1)}$ 、吉川博子 ${ }^{11}$ 、 辻なつき1)、熊倉英利香 ${ }^{1)}$ 、寺川耕市 ${ }^{1)}$ 、弓場吉哲 ${ }^{2)}$

\section{Laparoscopically resected mesothelial cyst mimicking a urachal cyst}

Atsuko Sakakibara $^{1)}$, Tadayoshi Nagano ${ }^{1)}$, Mari Ujita ${ }^{1)}$, Yusuke Butsuhara ${ }^{1)}$, Hiromi Miyata ${ }^{1)}$, Hiroko Yoshikawa ${ }^{1)}$, Natsuki Tsuji ${ }^{1)}$, Erika Kumakura ${ }^{1)}$, Koichi Terakawa ${ }^{1)}$, Yoshiaki Yuba ${ }^{2)}$

Department of Obstetrics and Gynecology ${ }^{1)}$,

Department of Pathology

The Tazuke Kofukai Medical Research Institute, Kitano Hospital

Objective: To report a rare case of a mesothelial cyst in the lower abdominal extraperitoneal space, mimicking a urachal cyst.

Case: A 43-year-old nulligravid female complained of lower abdominal pain, ongoing for about 6 months. Physical examination revealed a pelvic mass reaching the height of the umbilicus. Magnetic resonance imaging showed a $15 \times 6$ $\mathrm{cm}$ cystic tumor in addition to a uterine leiomyoma and an ovarian endometriotic cyst. Laparoscopic surgery revealed that the huge cystic tumor extended into the lower abdominal extraperitoneal space, similar to a urachal cyst, and was adherent to the ovarian endometriotic cyst. The resected tumor was diagnosed pathologically as a mesothelial cyst.

Conclusion: Mesothelial cysts occur most frequently in the peritoneal cavity of reproductive-aged women and are often accompanied by endometriosis. Endometriosis is often associated with pelvic peritoneal defects. This report suggests that a mesothelial cyst may extend into the lower abdominal extraperitoneal space through a peritoneal defect caused by endometriosis.

Key words: mesothelial cyst, endometriosis, pelvic peritoneal defect

\section{緒言}

mesothelial cystは、一般に骨盤内に多く ${ }^{1)}$ 、後 腹膜腔や大網 ${ }^{2.3)}$ 、鼠径ヘルニア囊を巻き达む事も ある4) と言われているが、本症例のように尿膜管 囊胞に類似した形態で、腹腔外に発育した報告は ない。その名称は様々で、multicystic mesothelioma、(multilocular) peritoneal inclusion cysts、 inflammatory cysts of the peritoneum、 pseudocyst などと呼ばれる。mesothelial cystは、癒着により 形成された空間に液体が貯留してできたもの で、典型的には、性成熟期女性に発生することが 多い1,6,7)。また、卵巣による腹水産生が、その成 因に大きく関わると言われている。 今回内膜症に合併したmesothelial cystが、尿 膜管囊胞に類似して腹腔外に巨大囊胞として発育 し、術中診断に迷ったものの腹腔鏡下手術で摘出 した症例を経験したので報告する。

\section{症例}

症例：43歳、未経妊

主訴：下腹部痛

既往症: 38 歳胆石症の診断で胆囊摘出術（開腹） 月経歴：初経12歳月経不順 月経痛軽度 月経 量やや多い

現病歴：数ヶ月前より持続する下腹部痛を認め、 近医産婦人科を受診し、MRIで子宮筋腫および卵 巣囊腫を指摘され、手術施行目的で紹介受診とな 
つた。

初診時診察所見：上腹部正中に縦切開手術痕を認 めた。BMI34の中等度肥満のため、内診所見は不 十分であったが、下腹部正中に、臍高に達する軟 な腫瘤を触知し、圧痛は明らかではなかった。

血液検查所見 : CA19-9; $143.9 \mathrm{U} / \mathrm{ml} 、 \mathrm{CA} 125 ; 55 \mathrm{U} /$ $\mathrm{ml} 、 \mathrm{CEA} ; 3.4 \mathrm{ng} / \mathrm{ml} 、 \mathrm{Hb} ; 12.3 \mathrm{~g} / \mathrm{dL} 、 \mathrm{WBC} ; 7800 /$ $\mu \mathrm{L} 、 \mathrm{CRP} ;<0.1 \mathrm{mg} / \mathrm{dL}$

MRI所見：子宮前壁に $5 \mathrm{~cm}$ 径の子宮筋腫を認め た。また、子宮の頭側に $4 \mathrm{~cm}$ 径のT1高信号、T2 やや高信号の病変を認め、左卵巣内膜症性囊胞を 疑った。これらに接し、さらに腹側にT1低信号、 $\mathrm{T} 2$ 高信号の $15 \times 6 \mathrm{~cm}$ の巨大囊胞を認め、卵巣漿 液性囊胞腺腫または炎症性囊胞を疑った。悪性を 示唆する所見は認めなかった（図 $1-a, b) 。$

\section{図 1-a MRI矢状断T1強調画像}

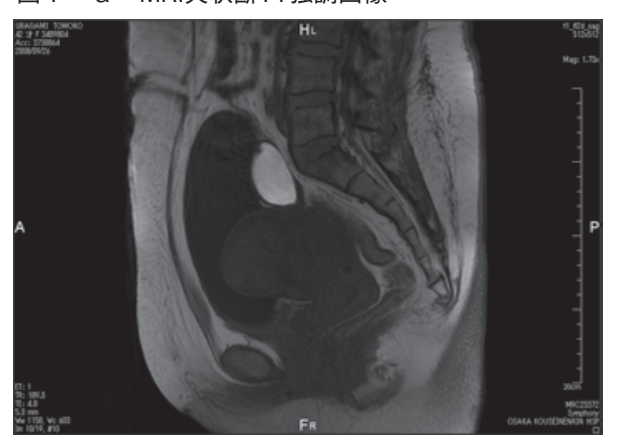

図 1-b MRI矢状断T2強調画像

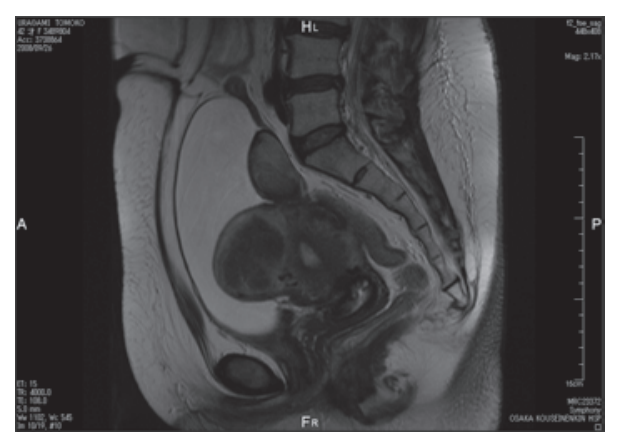

初診後経過： 6 ケ月間経過観察したが、巨大囊胞 の大きさは著変なく、下腹部痛が持続するため、 巨大囊胞の診断および摘出と、卵巣囊腫核出のた め、腹腔鏡下手術を施行した。筋腫については、 画像上一部内膜に近接する部分を認め、年齢より 今後増大し過多月経を来す可能性があると判断し たため、同時に核出術を施行した。

手術所見：クローズド法にて $5 \mathrm{~mm}$ トロカールを 挿入した後、左右上前腸骨棘内側にそれぞれ $12 \mathrm{~mm}$ と $5 \mathrm{~mm}$ のトロカールを挿入し、 $5 \mathrm{~mm} 30$ 度のスコープで、腹腔内を観察した。問題の巨大
豪胞は、下腹部正中の壁側腹膜に覆われた新生览 頭大の軟な腫瘤で、腹腔外に存在していた。術中 所見では、その存在位置より、尿膜管囊胞を疑っ た（図 $2-\mathrm{a})$ 。まず左卵巣囊腫を穿刺し、チョ コレート様の内溶液を認めた。続いて腹壁を軽く 圧排し、刺入位置と巨大囊胞との距離が十分であ ることを確認した上、下腹部正中に $5 \mathrm{~mm}$ のトロ カールを挿入した。気腹下では、巨大霊胞と臍と は比較的距離があった。巨大囊胞を覆う壁側腹膜 にハーモニックで切開を加え、巨大囊胞壁を把持 し、周囲から剥離したところ、暗紫色の巨大囊胞 壁を認めた。これは尿膜管囊胞に類似して、下腹 部正中の腹直筋後面の筋膜と腹膜の間に存在し、 膀胱を背側より圧排していた。この巨大囊胞を穿 刺すると、初めは赤褐色漿液性の液体を数 $10 \mathrm{cc} 、$ 続いて黄色透明漿液性の液体を500cc程吸引した (図 $2-\mathrm{b}$ )。続いて、この巨大囊胞に切開を加え スコープを挿入し、囊胞内部を観察すると、内壁 は平滑で、背側に子宮筋腫により裏打ちされた膨 隆を認めた（図 $2-\mathrm{c}$ )。一方、腹腔内所見は、 ダグラス窩が閉鎖し、左卵巣囊腫は、この巨大囊 胞に強固に癒着していた（図 $2-\mathrm{d}$ )。術中所見 では尿膜管囊胞の可能性が否定できなかった。し かし、剥離により膀胱との境界を明らかにするに は、癒着のため膀胱損傷のリスクがあると判断し、 泌尿器医にコンサルトの上、膀胱と巨大霊胞との 剥離は一部にとどめ、3 分の 1 程度尾側の囊胞壁 を残す形で核出した。続いて筋腫核出と左卵巣囊 腫核出を加え、核出した筋腫はモルセレーターで 回収し、筋層を数層に単結節縫合した。手術時間 は2時間13分、出血は少量であった。

摘出標本：巨大囊胞の壁は薄く暗紫色で充実部を 認めなかった（図 3 )。

病理所見：巨大襄胞のHE弱拡大では、震胞壁は 線維性で、内腔面に、異型にそしい立方から扁平 状の細胞が一層に配列し、壁内にはリンパ球浸潤 を認めた（図 $4-\mathrm{a}$ )。また、免疫染色で、中皮 のマーカーであるcalretinin, CK5/6は陽性、リン パ管内皮で陽性となるD2-40は陰性であった（図 $4-\mathrm{b})$ 。以上より、腹腔外に認めた巨大震胞は、 mesothelial cystと診断した。他の術中摘出標本 については、術前臨床診断と同じく平滑筋腫抒よ び内膜症性囊胞の術後病理診断を得た。また、持 続していた下腹部痛は術後消失した。

術後薬物療法を行わなかったが、mesothelial cyst㧍よび内膜症性囊胞について、現在に至る 2 年10ヶ月の間、再発を認めていない。 
図2－ａ巨大囊胞と左卵巣囊腫

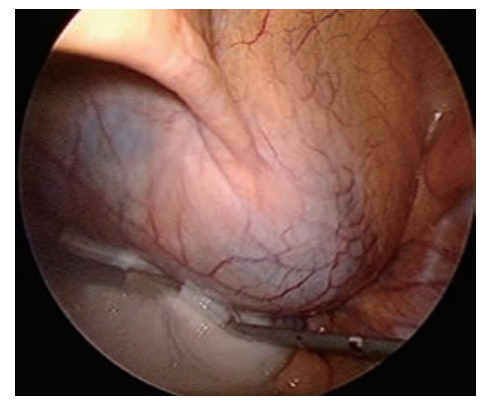

図 2ーb 壁側腹膜より剥離した巨大囊胞

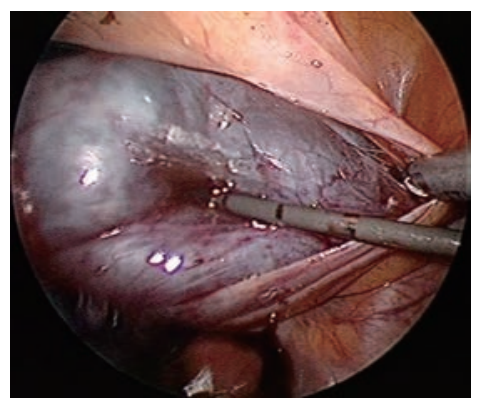

図2-c 巨大囊胞内部

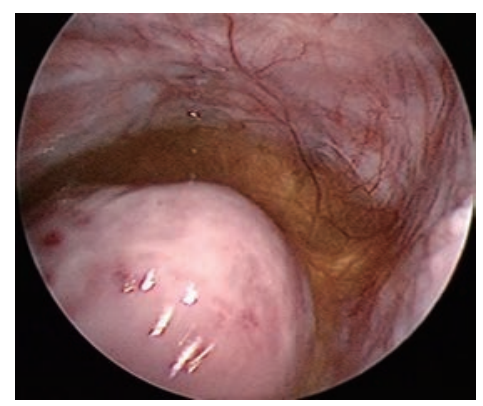

図 $2-\mathrm{d}$ 巨大囊胞と左卵巣囊腫との癒着

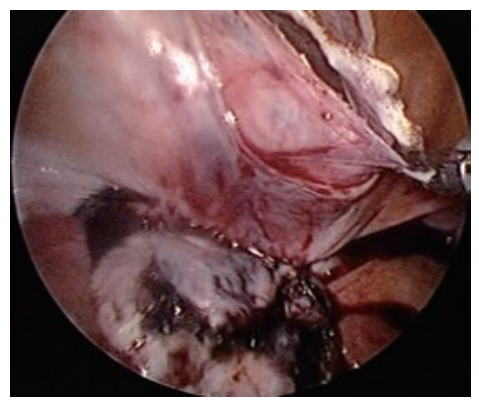

図 3 摘出標本 巨大囊胞壁（ホルマリン固定後）

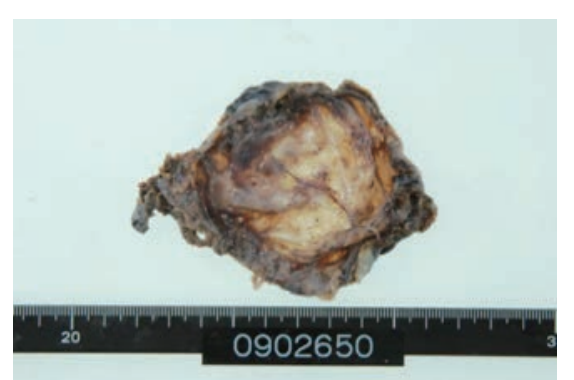

\section{図 4-a 巨大囊胞壁の病理組織所見}

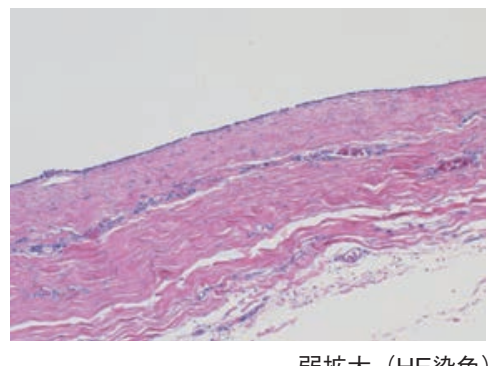

弱拡大 (HE染色)

\section{図 4-b 巨大囊胞壁の病理組織所見}

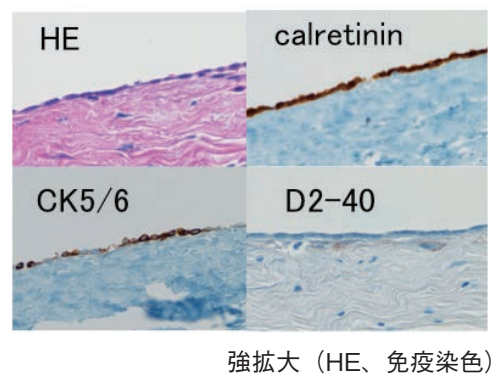

考察

mesothelial cystは、一般に骨盤内に多く ${ }^{1)}$ 、腹 腔外に発育することはまれである。本症例は、卵 巣と強固に癒着し、内膜症を合併していたことか ら、稀な発育形態をとったものと考える。

臨床的にmesothelial cystは、性成熟期女性の 腹腔内に発生することが多い ${ }^{1,6,7)}$ 。主な症状は、 持続する下腹部の不快感や疼痛で、既往手術・ PID・内膜症に伴うことが多い ${ }^{1,6-8)}$ 。 mesothelial cyst の成因については、腹膜の障害による体液 の漏出および吸収の不均衡と、卵巣による腹水の 産生が指摘されている。腹膜が障害を受けると、 炎症により多量のフィブリノーゲンを含んだ浸出 物が産生され、フィブリン塞栓となってリンパ管 や毛細血管を閉塞させ、腹水の吸収が障害される ${ }^{9)}$ と言う。また、同時におこる癒着により閉鎖腔が 形成され、腹水が貯留すると考えられる ${ }^{5)}$ 。さら に、mesothelial cystが性成熟期女性に多いこと については、Koninckxらによる次の報告が参考 になる。即ち、腹水産生について、正常月経周期 女性では、卵胞期に著明に増加し、黄体早期をピ ークに減少を認めたが、閉経後萎縮内膜女性やピ ル内服により卵巣が不活化している女性では、腹 水量はいずれも低下していた。これらの結果より、 腹水量は、活動性の卵巣表面から分泌される腹水 産生が大きく関与している ${ }^{10)}$ と考えられる。上 述に関連し、mesothelial cystは卵巣との癒着が 
多い7)ことが指摘されており、画像所見において、 正常卵巣に接して単房性または多房性の襄胞を認 める場合、mesothelial cystを診断する上での参 考になる ${ }^{5,11)}$ と言う。本症例は、MRIで巨大囊胞 は左卵巣囊腫に接し、また、術中所見で左卵巣囊 腫と強固に癒着しており、巨大異胞生成について、 卵巣による腹水産生を介した関与を推測する。ま た本症例は、上腹部正中切開による胆囊摘出術の 既往があるものの上腹部に癒着を認めず、子宮・ 付属器中心に内膜症によると推測される癒着が存 在しており、成因として既往手術の影響は低いと 考えられた。mesothelial cystの病理学的特徴と して、一層の扁平または立方形の悪性所見のない 中皮細胞が囊胞壁を覆っており、急性または慢性 炎症細胞を伴う繊維性間質の増生を認める ${ }^{2,6)} こ$ とが挙げられる。本症例でもこの所見に一致して おり、免疫染色の結果もこれを支持していた。一 方尿膜管囊胞では、移行上皮または立方上皮に覆 われている事が多く、円柱上皮や扁平上皮の報告 もあるが、巨大囊胞壁に上皮を認めなかった事か ら否定された。臨床的に、mesothelial cystが内 膜症に合併することが多い6) と言われるが、病理 学的観点からも内膜症が成因の一つとして、強く 関与していることを示す報告 ${ }^{28,12)}$ がある。本症例 において、病理学的に巨大囊胞壁内には内膜症の 所見を認めなかったが、接していた左卵巣囊腫は 内膜症性囊胞の診断であった。そもそも内膜症は、 炎症と腹膜の癒着を伴い易く、性成熟期女性に多 いという特徵があり、mesothelial cystの成因を 考慮すれば、互いに合併し易いことは理解できる。 加えて、腹膜欠損は、骨盤痛・月経困難などを主 訴として診断的腹腔鏡手術を受けた女性患者の 4 $-17 \%$ 々られ、そのうちの $7-8$ 割に内膜症が 関与している ${ }^{13,14)}$ という報告があり、内膜症と腹 膜欠損は関連が深い。以上の事から推測すると、 本症例における稀な存在位置の説明として、内膜 症による腹膜欠損部から mesothelial cystが腹壁 下に発育し、尿膜管囊胞に類似した形態をとった ものと推測される。また、術前CA19-9 C CA 125 の上昇を認めていたが、術後それぞれ46-68U/ $\mathrm{ml}$ および26-40U/mlの值を推移し、2 年経過後 ほぼ正常範囲となった。mesothelial cystは一般 に腫瘍マーカーが正常であり、術前に認めた CA19-9 とCA125の上昇は、子宮内膜症の影響に よるものと考える。

臨床所見では尿膜管囊胞に特徵的とされる膀胱 刺激症状・血尿・感染所見・CEA上昇 ${ }^{15)}$ は認めず、
MRI所見でも尿膜管囊胞の特徵である膀胱頂部や 臍と腫瘤の連続性 ${ }^{15,16)}$ は認めなかった。今回、術 中所見が尿膜管囊胞に類似し判断に苦慮したが、 腹腔鏡下手術で摘出し得た。mesothelial cystは 卵巣腫瘍との鑑別が困難であり手術を選択しがち であるが、腹腔内の癒着のため手術の難易度が高 く、摘出しても再発が多いことから、可能であれ ば保存的治療が望まれる。その成因の観点から卵 巣機能抑制を目的とした、ホルモン療法 ${ }^{5)}$ や gonadotropin releasing hormone agonist (Gn$\mathrm{RHa}$ ）療法 ${ }^{17.18)}$ を勧める報告がある。本症例では 下腹部痛が持続し、大きさが大きいため、診断を 兼ねて手術を施行した。mesothelial cystは確定 診断や治療のために手術が必要な時があるが、侵 襲の少ない腹腔鏡下手術も選択肢の一つであると 思われた。

本論文の要旨は、第 10 回近畿産婦人科内視鏡手 術研究会 (2010年 2 月 於大阪)、第50回日本産 科婦人科内視鏡学会 $(2010$ 年 7 月 於東京)、に おいて発表した。

\section{文献}

1 ) Weiss SW, Tavassoli FA.: Multicystic mesothelioma. An analysis of pathologic findings and biologic behavior in 37 cases. Am J Surg Pathol 1988; 12(10): 737-46.

2 ) Groisman GM, Kerner H.: Multicystic mesothelioma with endometriosis. Acta Obstet Gynecol Scand 1992; 71(8): 642-4.

3 ) Soreide JA, Soreide K, Korner H, et al.: Benign peritoneal cystic mesothelioma. World J Surg 2006;30(4): 560-6.

4) Harper GB, Jr., Awbrey BJ, Thomas CG, et al.: Mesothelial cysts of the round ligament simulating inguinal hernia. Report of four cases and a review of the literature. Am J Surg 1986; 151(4): 515-7.

$5)$ Hoffer FA, Kozakewich H, Colodny A, et al.: Peritoneal inclusion cysts: ovarian fluid in peritoneal adhesions. Radiology 1988; 169(1): 189-91.

6 ) Ross MJ, Welch WR, Scully RE.: Multilocular peritoneal inclusion cysts (so-called cystic mesotheliomas). Cancer 1989; 64(6): 1336-46.

7 ) McFadden DE, Clement PB.: Peritoneal inclusion cysts with mural mesothelial proliferation. A clinicopathological analysis of six cases. Am J Surg Pathol 1986; 10(12): 844-54.

8 ) Kerner H, Gaton E, Czernobilsky B.: Unusual ovarian, tubal and pelvic mesothelial inclusions in patients with endometriosis. Histopathology 1981; 5(3): 277-83. 
9 ) Falk H.: Intraperitoneal cysts simulating ovarian cysts; diagnosis and treatment. Obstet Gynecol 1953; 1(183-187).

10) Koninckx PR, Renaer M, Brosens IA: Origin of peritoneal fluid in women: an ovarian exudation product. Br J Obstet Gynecol 1980; 87: 177-83.

11) Kim JS, Lee HJ, Woo SK, et al.: Peritoneal inclusion cysts and their relationship to the ovaries: evaluation with sonography. Radiology 1997; 204(2): 481-4.

12) Kurisu Y, Tsuji M, Shibayama Y, et al.: Multicystic mesothelioma caused by endometriosis: 2 case reports and review of the literature. Int J Gynecol Pathol 2011; 30(2): 163-6.

13) Chatman DL.: Pelvic peritoneal defects and endometriosis: Allen-Masters syndrome revisited. Fertil Steril 1981; 36(6): 751-56.

14) Chatman DL, Zbella EA.: Pelvic peritoneal defects and endometriosis: further observations. Fertil Steril 1986; 46(4): 711-4.

15）太田晶一郎.: 尿膜管囊胞の臨床的検討. 泌尿器外科 1995; 8(9): 737-40

16）菊池 勤: MRIが診断に有用であった尿膜管囊胞の 2 例. 臨床外科 1997; 52(12): 1495-98.

17) Kurachi H, Murakami T, Maeda T, et al.: Value of gonadotropin-releasing hormone agonist in diagnosing peritoneal pseudocysts. Acta Obstet Gynecol Scand 1996; 75(3): 294-7.

18）岩田 卓:: Peritoneal inclusion cyst 囊胞性卵巣腫瘍 との鑑別. 産科と婦人科 2007; 74(6): 676-83. 